Southern Methodist University

SMU Scholar

Summer 8-23-2017

\title{
Do Latinos Still Support Immigrant Rights Activism? Examining Latino Attitudes a Decade After the 2006 Protest Wave
}

\author{
Chris Zepeda-Millán \\ University of California, Berkeley, czm@berkeley.edu \\ Sophia Jordán Wallace \\ University of Washington, sophiajw@uw.edu
}

Follow this and additional works at: https://scholar.smu.edu/latino-policy

Part of the American Politics Commons, Civic and Community Engagement Commons, Politics and Social Change Commons, Public Policy Commons, and the Race and Ethnicity Commons

\section{Recommended Citation}

Zepeda-Millán, Chris and Jordán Wallace, Sophia, "Do Latinos Still Support Immigrant Rights Activism? Examining Latino Attitudes a Decade After the 2006 Protest Wave" (2017). Latino Public Policy. 3.

https://scholar.smu.edu/latino-policy/3

This document is brought to you for free and open access by the SMU Tower Center at SMU Scholar. It has been accepted for inclusion in Latino Public Policy by an authorized administrator of SMU Scholar. For more information, please visit http://digitalrepository.smu.edu. 


\title{
Do Latinos Still Support Immigrant Rights Activism? Examining Latino Attitudes a Decade After the 2006 Protest Wave
}

\begin{abstract}
:
The historic and primarily Latino 2006 immigrant rights protest wave occurred in response to proposed federal anti-immigrant legislation (H.R. 4437). Research on the unprecedented series of demonstrations suggests that the draconian and racialized nature of the bill helps explain why it incited large-scale collective action. Utilizing a new survey with a considerable oversample of Latino respondents, the 2016 Collaborative Multiracial Post-Election Survey (CMPS), this paper investigates contemporary Latino support for immigrant rights activism. We examine several factors that influence support such as linked fate, knowing undocumented people, perceptions of anti-immigrant sentiments, concerns about immigration enforcement policies, political party identification, and past participation in protests. The results of our analysis indicate that some of the same factors that influenced Latino engagement in the 2006 mobilizations, such as identity, threat, concerns over enforcement, and racialization, continue to impact Latino support for contentious politics on behalf of the foreign-born. We also find evidence that political party, past protest activity, and the composition of one's social network also play a significant role in explaining levels of support for activism. Our results have important implications for understanding how anti-immigrant policies and racialized nativism influence Latino support for contentious politics.
\end{abstract}

\author{
Sophia Jordán Wallace ${ }^{1}$ \\ Associate Professor \\ University of Washington \\ Department of Political Science \\ sophiajw@uw.edu \\ Chris Zepeda-Millán \\ Assistant Professor \\ University of California, Berkeley \\ Department of Ethnic Studies \\ czm@berkeley.edu
}

\footnotetext{
${ }^{1}$ Both authors contributed equally to this manuscript.
} 


\section{Introduction}

The 2006 immigrant rights protest wave was the largest episode of Latino collective action in U.S. history. The series of demonstrations, of which up to five million foreign- and U.S.-born Latinos and their allies took part, was in response to the Republican-controlled U.S. House of Representatives' passage of the draconian Border Protection, Anti-Terrorism, and Illegal Immigration Control Act of 2005 (H.R. 4437), more popularly known as the “Sensenbrenner Bill.” The proposed legislation would have effectively criminalized undocumented immigrants, their families, and anyone who associated with them in the most basic ways (DeSipio and de la Garza 2015: 16). As a result, the bill sparked a contentious and highly racialized debate that incited Latinos to take to the streets in defense of their families and their communities (Pallares and Flores-Gonzalez 2010; Voss and Bloemraad 2011; ZepedaMillan 2014).

All across the country, Latinos were united in their support for the nationwide rallies, which sought to stop the Sensenbrenner Bill and called for a path to citizenship for undocumented immigrants. To illustrate, according to a survey of Latinos conducted a few weeks after the protest wave by the Pew Research Center, a strong majority (58\%) of respondents believed Latinos were now "working together to achieve a common goal." In addition, while more than half (54\%) of those polled expressed seeing an increase in discrimination as a result of the immigration policy debate taking place, almost two-thirds (63\%) of Latinos felt "the pro-immigrant marches this year signal the beginning of a new and lasting social movement". ${ }^{2}$ Moreover, although contentious politics among Latinos has traditionally been regionally and ethnic specific (e.g. the Chicano Movement in the U.S. Southwest, or Puerto

\footnotetext{
${ }^{2}$ See http://www.pewhispanic.org/2006/07/13/2006-national-survey-of-latinos/.
} 
Rican activism in New York and Chicago), the series of marches in 2006 garnered widespread support amongst Latinos across all national origin groups (Barreto et al. 2009: 756). ${ }^{3}$ For instance, when asked if "The marches showed that Latinos - immigrant or not - are united and won't put up with discrimination any longer," $78 \%$ of Mexican, $73 \%$ of Puerto Rican, $81 \%$ of Dominican, $74 \%$ of Cuban, $68 \%$ of Central American, and $75 \%$ of South American Latinos agreed with this bold and efficacious statement (Barreto et al. 2009: 756).

Clearly, during the 2006 demonstrations, many Latinos embraced immigrant rights activism when facing a racially discriminatory legislative attack (H.R. 4437) (Pedraza et al. 2011; Zepeda-Millán 2016). These findings are particularly relevant today given the results of the 2016 presidential election. From claiming that Mexicans were rapists, to his campaign promise to build a wall along the U.S.'s southern border, Donald Trump is undoubtedly the most openly anti-Latino president in American history. Thus, with an overt nativist in the Oval Office and the Republican Party now firmly in control of both the executive and legislative branches of the federal government for the first time since the 2006 protest wave, it is an opportune time to once again explore the relationship between nativist immigration policies, Latino identity, and their sentiments toward contentious politics on behalf of the foreign-born today. Contributing to research on social movements, Latino politics and immigration, our findings suggest that over a decade after the historic demonstrations, racialized policy threats continue to augment Latino support for immigrant rights activism.

\section{Theoretical Background}

\section{Social Movements and Public Opinion}

\footnotetext{
${ }^{3}$ Barreto et al.'s survey found that found that on a scale of 1 to 10, Latinos of Mexican (7.8), Puerto Rican (7.8), Dominican (7.7), Central American (7.3), South American (7.1), and even of Cuban (7.2) descent, all expressed high levels of support for the rallies.
} 
Public observers of activism do not always remain inactive witnesses; they can become sympathetic to movement causes and even be inspired and motivated to join in on the action (Gamson 2007: 242). But while scholars of contentious politics have extensively studied how activists attempt to frame their claims to their target audiences (Benford 1993; McCammon 2001; Ferree et al. 2002; Snow 2007), the relationship between social movements and public opinion has received insufficient attention in the literature (Vrablikova 2013). Studies of activism that do consider people's attitudes have highlighted some important aspects of this understudied topic, such as how protests impact policy outcomes via public opinion (Costain and Majstorovic 1994; Guigni 2004; Lieberfeld 2009), how activism influences people's thoughts on specific issues (Everitt 1998; Lee 2002; Banaszak and Ondercin 2009), the effects of mass mobilizations on identities (Zepeda-Millan and Wallace 2013), feelings of group solidarity (Barreto et al. 2009; Jones-Correa et al. 2016), political efficacy and trust in government (Pedraza et al. 2011; Wallace et al. 2014). Nevertheless, in order to understand the full dynamics of large-scale collective action, examining the factors that increase public approval for contentious politics is also essential given that supportive public opinion is a critical precondition to organizing sizeable and successful protests (Vrablikova 2013: 1023).

Surprisingly, as Andrews et al. (2016: 1) point out, despite one of the chief goals of political actors being to gain public sympathy, a key question yet to be thoroughly investigated by social movement scholars is, "Why do some citizens but not others approve when activists use protest tactics?" Put another way, given the array of traditional modes of political expression (i.e. voting, singing petitions, lobbying, making campaign contributions) available as possible means for achieving desired outcomes, what (if any) factors drive public support for activism? This question is especially important for movement organizers because if they hope to draw the 
public to their causes, then it is vital that they know whether their target audiences support their chosen tactics. Hence, gauging these sentiments is imperative because public support for activism can give activists a sense of the reservoir of potential movement allies and participants (Oegema and Klandermans 1994; Klandermans 1984). For our purposes, we are particularly interested in the factors that impact Latino support for immigrant rights activism given the current nativist and anti-Latino climate in the United States. While, to our knowledge, there is very little social scientific research that explicitly focuses on Latino public opinion about political activism, we believe that research on the Latino racialization of U.S. immigration, linked fate, concerns over punitive immigration enforcement, and social networks may provide some valuable clues that can help us begin to understand this phenomenon.

\section{Immigration, Racialization, and Social Networks}

Several scholars have demonstrated that one of the primary ways Latinos in the United States are racialized is through nativist immigration policies (Ngai 2005; De Genova 2004). Because the alleged undesirable characteristics of immigrants of color are often extended to U.S.-born citizens of color (Bloch 2014; Johnson 2004), some researchers argue that negative portrayals of undocumented Latino immigrants lead to Latinos in general - American- and foreign-born - to be viewed by the larger U.S. public as potential "illegal alien threats" (Chavez 2008; Ponce 2014; Rocco 2014). One consequence of this racist stereotyping is that, "Despite the fact that most Latinos are not undocumented and that not all of the undocumented are Latino," in many respects, to be Latino has become "synonymous with being undocumented and to be undocumented is synonymous with being Latino" (Gonzales et al. 2014: 166; see also Masuoka and Junn 2013: 82). As Abrajano and Hajnal (2015) conclude, while in theory "categories like undocumented immigrant, legal immigrant, and Latino are all distinct from each other," in the 
"practice of US politics, these concepts often blur together" (17). But while these studies help us comprehend the relationship between immigration and Latino racialization, they say very little about how this phenomenon impacts Latinos' opinions about political activism. Here the literatures on group consciousness and political participation are informative.

Group consciousness is a form of in-group identification that is politicized "by a set of ideological beliefs about one's group's social standing, as well a view that collective action is the best means by which the group can improve its status and realize its interests" (McClain et al. 2009, 476). The concept of "linked fate" draws from this understanding of group consciousness, but is different in that it "explicitly links perceptions of self-interest to perceptions of racial group interests" (Dawson 1994: 76). Michael Dawson (1994: 77) explains that linked fate captures a situation in which racial group interests serve as "a useful proxy for self-interest." Research on Latino group consciousness and linked fate reveal that these sentiments are more pronounced when Latinos perceive group discrimination and especially when they are being targeted by nativist public policies (Sanchez 2006a; Valdez 2011; Vargas et al. 2017; see also Massey and Sanchez 2010).

These findings are critical to note because despite the fact that Latinos are amongst the least likely groups to take part in contentious politics (Martinez 2005: 140; Verba, Schlozman, and Brady 1995: 234-235), both quantitative and qualitative studies have demonstrated that increased levels of linked-fate and group consciousness, as well as racialized nativist legislative threats, can prod Latinos into participating in political activism (Stokes 2003; Garcia Bedolla 2005; Sanchez 2006b Martinez 2008; Okamoto and Ebert 2010; Zepeda-Millan 2016). As Rumbaut (2007) contends, anti-immigrant policies can have the "unintended consequences" of accentuating group differences and hardening ethnic boundaries, leading to the promotion of 
"ethnic group solidarity and political mobilization" (3). However, although these studies have important implications for understanding Latinos' willingness to participate in political activism, we still know very little about whether the general Latino public is sympathetic towards these types of actions, and, if so, what factors drive these sentiments. Because social networks are key to recruiting individuals to take part in contentious politics (Diani and McAdam 2003), it is imperative to explore whether support for activism on behalf of a certain group will be greater among people who know someone who is part of that group.

Research has shown that immigration is a highly personal and salient issue to Latinos in part because of how it affects their families, neighbors, friends, and communities (Wallace 2012; Sanchez et al. 2015). In fact, these types of personal social networks played a key role in motivating and mobilizing many Latinos to participate in the historic 2006 protest wave (Bloemraad and Trost 2008; Zepeda-Millan 2016). Thus, because the vast majority of Latinos in the U.S. are either foreign-born themselves or "are children, spouses, in-laws, and neighbors" of immigrants (Pedraza, Segura, and Bowler 2011: 2), we expect that individuals who know someone who is undocumented or fear that anti-immigrant policies may impact someone they personally know, will be more likely to support immigrant rights activism.

In sum, while the literature on the Latino racialization of immigration helps us understand the links between Latino identity and the issue of immigration, it says relatively little about how this phenomenon impacts Latinos' opinions about political activism in defense of the foreignborn. Correspondingly, research on linked-fate and political participation suggests that antiimmigrant policies can increase the likelihood that some Latinos will engagement activism, but says almost nothing about how the general Latino public views these types of political actions. Lastly, research on the 2006 marches shows that social networks played key roles in facilitating 
participation in the series of demonstrations, but we don't know whether knowing people who are undocumented or vulnerable to punitive immigration policies continues to motivate support for immigrant rights activism today. Thus, given the valuable insights gained from the literatures reviewed above, we posit that Latinos who feel negatively racialized by anti-immigrant sentiments, who display higher levels of linked-fate, or who know someone who is undocumented or who may be impacted by punitive immigration enforcement measures, will also be more supportive of immigrant rights activism.

\section{Research Design}

Much of the existing work on Latinos and the immigrant rights movement tends to focus on Latinos as political actors within the movement (Milkman and Terriquez 2012; Nichols 2013; Terriquez 2015), the development and dynamics of the 2006 protest wave (Pallares and FloresGonzalez 2010; Voss and Bloemraad 2011; Zepeda-Millán 2017), or on how exposure to the 2006 demonstrations impacted Latino attitudes (Wallace et al. 2014; Jones- Correa et al. 2016; Zepeda-Millán and Wallace 2013). Using the new 2016 Collaborative Multiracial Post-Election Survey (CMPS), our analysis focuses on Latino support towards immigrant rights activism.

A common issue in examining Latino public opinion is the dearth of widely available data that includes a sufficiently sized sample to examine variation among Latinos. For example, on the Cooperative Congressional Election Survey (CCES), Latinos usually make up only $15 \%$ or less of the sample. On the American National Election Studies (ANES) in 2012, the ANES oversampled Latino respondents to get a total of just over 1,000 Latino respondents. In 2016, the total Latino sample size in the ANES was smaller than in 2012, obtaining only 450 Latino respondents. Thus, even with the increased Latino sample on the ANES, there is not enough variation across key variables such a generation status, national origin group or nativity to 
examine in-group variation in depth. With regards to substantive questions on protests, the ANES contains only a single item which asks respondents if they participated in a march or rally over the past year. The Latino National Survey (2006) has a large Latino sample of 8, 346 respondents (Fraga et. al 2006), however similar to both the ANES and CCES, it lacks questions on support for activism in general, or in specific areas such as immigrant rights and does not include the ANES question about past participation in marches. This paper fills this gap in the literature by analyzing Latino support for immigrant rights activism on a large Latino sample.

The CMPS was designed to include a sample of approximately 3,000 Latino respondents, in addition to 3,000 African-American, 3,000 Asian, and 1,000 White respondents. The survey was conducted after the 2016 election and was in the field from December 2016 through midFebruary 2017. The polling firm Latino Decisions fielded the survey in conjunction with Pacific Market Research. The survey was conducted online and respondents were given a choice to take the instrument in Spanish, English, Chinese (simplified), Chinese (traditional), Korean, or Vietnamese. Latino respondents took the instrument exclusively in Spanish or English. The survey was composed of questions that teams of researchers designed. There were contributions from 86 individual researchers from 55 different universities. Researchers purchased time on the survey to field their survey content and together these resources were then pooled, which allowed for the fielding of a comprehensive instrument with substantial oversamples of Latino, African-American, and Asian respondents. Researchers could field their questions on the entire sample or any array of the samples based on racial or ethnic groups. ${ }^{4}$ We constructed a series of questions fielded on the Latino sample of 3,003 respondents and utilize several of these items for

\footnotetext{
${ }^{4}$ More information about the CMPS survey can be found here http://www.latinodecisions.com/recent-polls/cmps2016/
} 
the analysis in this article. ${ }^{5}$ The survey also included a battery of various common sociodemographic variables, including gender, political party affiliation, national origin group, income, and education. ${ }^{6}$

To analyze Latino support for immigrant rights activism, our survey item asked respondents: "How strongly do you support or oppose immigrant rights activism?” Respondents could then select one of the following answer choices: "Strongly Support," "Somewhat Support," "Neither Support or Oppose," "Somewhat Oppose," "Strongly Oppose." For the purposes of this analysis, we created a modified 3-point measure that collapses together the two degrees of support and opposition respectively. ${ }^{7}$ This variable serves as our main dependent variable and directly measures Latino support for immigrant rights activism. Our expectation is that respondents are familiar with the phrase "immigrant rights activism" because Spanish-language media has been shown to be more sympathetic to the plights of immigrants (Abrajano and Signh 2009; Brown and Lopez-Sanders 2017) and frequently covers activism related to immigration issues (Felix et al. 2008; Aparicio 2010; Ramirez 2011). Our expectation is that respondents will understand immigrant rights activism to mean forms of protests such as rallies, marches, and demonstrations. ${ }^{8}$ As such, we feel confident that our survey is capturing respondents' opinions

\footnotetext{
${ }^{5}$ A full list of substantive survey items used in the models is included in the Appendix.

${ }^{6}$ A table of descriptive statistics of the variables is included in the Appendix in Table A1.

${ }^{7}$ The main dependent variable thus measures attitudes toward immigrant rights activism as Support / Neither support or oppose / Oppose. The three-point measure is utilized because of the necessity to use survey weights and the calculation of substantive effects when utilizing survey weights. For robustness, we also ran the regression model using the five-point dependent variable and the statistical results are the same. The results of this alternate model specification are contained in the Appendix in Table A2.

${ }^{8}$ We do not include a variable for Spanish language media reliance in our main model because the proportion of Latino respondents who rely primarily on Spanish language media in the CMPS sample is small (7.3\%). We ran an additional model using a Spanish media reliance variable and the results for this variable are not statistically significant. While we do think there is a relationship between Spanish language media reliance and support for immigrant rights activism given the role of Spanish media in 2006 protests, there are too few CMPS respondents who are Spanish media dominant to appropriately demonstrate this relationship. An examination of raw levels of support for immigrant rights activism indicates that $69 \%$ of Spanish media dominant respondents support immigrant rights activism compared to $49 \%$ of respondents who are English media dominant.
} 
about "immigrant rights activism" in particular and not simply their attitudes about immigration or protests in general. ${ }^{9}$

We conducted ordered logistic regression due to the ordinal nature of the dependent variable (Long and Freese 2014). To fully specify the models and take into account any differences in this sample from the general adult Latino population in the United States, our models incorporates sample weights that were constructed based on the 2015 Census American Community Survey (ACS) data file. ${ }^{10}$ To investigate the role of various factors in explaining support for immigrant rights activism, we include a host of variables in our statistical models. To contextualize the role of Latino identity, concerns over immigration enforcement, racialization, one's social network, and past participation in protests, we employ five main variables. The first is a commonly used question assessing linked fate. The item asks respondents, "Do you think what happens generally to Latino/Hispanic people in this country will have something to do with what happens in your life?" As mentioned earlier, prior research has demonstrated that Latinos often feel a high degree of linked fate with one another, which can greatly influence their political attitudes (Sanchez 2006a; Sanchez and Masuoka 2010; Fraga et al. 2010; Fraga et al. 2011). Thus, we hypothesize that Latinos with a higher sense of linked fate with other Latinos will be significantly more likely to support immigrant rights activism because they likely view such activism as beneficial to the Latino community as a whole.

\footnotetext{
${ }^{9}$ More discussion of the results and potential alternative explanations for what the DV is measuring are contained in Fn. 12 on pg. 13.

${ }^{10}$ The Latino sample of CMPS is comparable to other large surveys of Latino respondents such as the LNS (2006). The ways in which the sample is most different than other Latino samples and the Latino adult population, is that the CMPS sample has more female respondents and is slightly skewed towards higher educated Latinos and younger Latinos. To balance for difference between our sample and the Latino adult population, we have utilized survey weights. A post-stratification ranking algorithm was used to balance the categories of age, gender, education, nativity, ancestry, and voter registration, within $+/-1$ point of the ACS estimates for each racial group. For more information, see http://www.latinodecisions.com/files/1214/8902/9774/cmps methodology.pdf. A table of descriptive statistics for the variables in this analysis is contained in the Appendix in Table A2.
} 
Prior research has shown threat can motivate Latinos to participate in activism. To measure the impact of concerns over punitive immigration enforcement policies on Latino support for activism we utilize a variable that asks respondents how worried they are about whether people they know will be detained or deported. We use this measure as a proxy to gauge feelings of anxiety and concern about immigration enforcement that may be detrimental to individuals in their lives. Research has shown that immigration is a highly personal and salient issue to Latinos in part because of how it affects their families, neighbors, friends, and communities (Wallace 2012; Sanchez et al. 2015). We expect that individuals who express high levels of concern about potential immigration enforcement will also be more likely to support immigrant rights activism.

Additionally, the studies cited earlier suggests that one of the primary ways Latinos in the United States are racialized is through discriminatory immigration policies. Accordingly, we use an item asking respondents whether they agree or disagree with the following statement: "Antiimmigrant sentiments are really anti-Latino sentiments." This item directly taps into perceptions of whether broader societal attitudes that are against immigrants inherently involve negative feelings towards Latinos as well (Abrajano and Hajnal 2015). We believe this question is capturing a sense of perceived racialization and expect those who agree with the statement to also be more likely to support contentious politics on behalf of the foreign-born.

To assess the role of social networks our models also incorporate a measure of whether respondents know someone who is undocumented. Given that undocumented people are the most likely targets in public discourse on immigration and immigration enforcement (Santa Ana 2002; Chavez 2013), and in the 2016 election were identified as a major problem by the Republican presidential candidate Donald Trump (Wang 2016), this measure allows us to directly assess 
whether individuals in the respondent's social network may be at risk. Because respondents may be concerned about people they know being vulnerable to immigration enforcement measures, they may view activism as a way to secure more rights and protections for undocumented members of their social networks. Thus, we posit that individuals who know people without papers will be more likely to support activism that seeks to advance the rights of immigrants.

To assess the role of past participation in protests on support for immigrant rights activism, we include a variable that asks whether respondents have participated in a protest, march, or rally in the last 12 months. Unfortunately, the question does not ask what the protest or march was substantively about. The survey does not contain any questions specific to immigrant rights marches or participation in the 2006 marches. Given the time frame of the last 12 months, the percentage of respondents who are likely to respond affirmatively to participating in a march is likely to be low as protests are a relatively infrequent event. Among Latino respondents, nearly $12 \%$ of respondents reported participating in a march or rally in the last 12 months. We include this variable because we believe that individuals who have engaged in activism may be more likely to support activism.

We also employed a set of control variables that are related to specific individual attributes of the survey respondents. Due to demonstrated differences in the Republican Party's restrictive and punitive position on immigration and Republican attitudes on immigration (Wroe 2008; Wong 2017), including amongst Latino Republicans, we include a measure for whether respondents identify as Republican. We predict that Republican respondents will be less likely to support immigrant rights activism. To examine the difference between higher income and lower income Latino respondents' levels of support, we use a 12-point scaled income variable. We also include a variable for whether respondents identify as male to examine potential gender 
differences in attitudes. To investigate differences in older respondents compared to younger respondents, the models contain a continuous age variable. The models also incorporate a measure of respondent's education level, which ranges on a six-point scale from completing grades 1-8, some High School, High school grad or GED, Some college, 4-year degree, or Postgraduate education. Additionally, we utilize a national origin variable that uses respondents' answers to a general ancestry question in order to create binary variables for whether respondents were of Mexican, Puerto Rican, Cuban, or Dominican ancestry. These groups were selected since they are the largest national origin groups within the U.S. Latino population (García Bedolla 2014). ${ }^{11}$ Finally, to explore differences between Latino respondents who were born in the United States and those who were not, we include a binary variable for whether a respondent was born in the U.S. We turn now to examine the results of the statistical models on support for immigrant rights activism.

\section{Results}

Overall, the raw levels of Latino support for immigrant rights activism are high in comparison to opposition, with $53 \%$ of respondents supporting ${ }^{12}$ and $11 \%$ opposing, and the rest of our respondents answering that they neither support or oppose. The level of support among different national origin groups was also high with, with $57 \%$ of Mexican, $49 \%$ of Puerto Rican, $58 \%$ of Dominican, and $53 \%$ of Cuban respondents supporting immigrant rights activism. The statistical results of the models indicate there are substantial differences amongst Latinos in their

\footnotetext{
${ }^{11}$ Respondents of all other national origin groups not specifically controlled thus represent the excluded, or baseline, category. The sample of respondents analyzed is entirely Latino respondents.

${ }^{12}$ One alternative explanation is that expressed levels of support for activism is actually capturing support for immigration overall. Latino support for pro- immigration policies is considerably higher (over $80 \%$ ) than the reported levels of support for activism (53\%). Thus, while many of the people who support pro-immigration policies may support activism on the issue as well, there is not a one to one overlap with those that support activism. Additionally, one may suggest that Latinos may express the same levels of support for activism overall and they would be similarly supportive of any other type of activism that is not immigrant rights related. In examining Latino support for Black Lives Matter $45 \%$ indicated support, while $58 \%$ indicated support of LGBT activism, thus there is variation in Latino support for activism on different issues.
} 
support for immigrant rights activism. Our findings provide strong evidence that variation in attitudes toward activism are influenced by factors related to Latino identity (linked-fate), knowing someone who is undocumented, fearing that someone they know may be impacted by anti-immigrant policies, and past protest activity. The results for Model 1 are presented in Table 1. ${ }^{13}$ Below we turn to discuss the main findings of the statistical model as well as the substantive effects in a thematic fashion.

\section{INSERT TABLE 1 HERE}

\section{Latino Identity, Nativist Immigration Policies, and Social Network}

As we hypothesized, Latinos who feel the highest sense of linked fate, who are worried about immigration enforcement measures negatively impacting someone they know, who know undocumented people, or see anti-immigrant sentiments as anti-Latino are all significantly more likely to support immigrant rights activism. Scholars have long demonstrated that linked fate amongst Latinos plays a very significant role in explaining Latino political attitudes. For example, Latinos with higher levels of linked fate are more likely to want more descriptive representation (Wallace 2014), and are more likely to be politically active (Sanchez 2006b; Masuoka 2008). Our results confirm that group identity, measured by linked fate, also plays a key role in explaining support for immigrant rights activism among Latinos. While only 34.9\% of the Latino community is foreign born (Brown and Stepler 2016), there are many Latinos with mixed status families and whose parents and/or grandparents were immigrants. Thus, immigration is an issue that affects large swaths of the Latino population in very direct ways. High identifiers who believe in linked fate may thus be more likely to support immigrant rights activism because they believe it would benefit Latinos as a group.

\footnotetext{
${ }^{13}$ All analysis conducted using Stata 14.
} 
Scholars studying the 2006 marches have shown that Latinos can be motivated to partake in political activism when people they know are being targeted by anti-immigrant policies (Zepeda-Millán 2017; Ramírez 2013). Our results indicate that nativist legislative threats also explain variation in support for immigrant rights activism among Latinos. As noted earlier, to measure the impacts of punitive immigration policies we utilize a question that asks respondents how worried they are about people they know being deported or detained. The results of the statistical models indicate that people who are the most worried about potential immigration enforcement measures impacting someone they know are also more likely to support immigrant rights activism.

In this context of attacks through nativist legislation and policies, Latinos have been racialized as a group (Ngai 2005; De Genova 2004). Some scholars assert that negative stereotyping of undocumented immigrants has been generalized to all Latinos (Chavez 2008) and has in some ways made undocumented synonymous with Latino (Gonzales et al. 2014; Masuoka and Junn 2013). Thus, it is not surprising, that we find that Latinos who perceive a link between anti-immigrant and anti-Latino sentiments are also more likely to support contentious politics on behalf of the foreign-born. These respondents feel the most racialized and are likely aware of how broader attacks on immigrants affect them as Latinos. Consequently, it seems like a logical extension that they would be in favor of extending rights for immigrants through activism.

Finally, closely related to our threat of immigration enforcement measure is a variable we used about whether the respondent knows someone who is undocumented. Knowing people who are potentially in direct danger from immigration enforcement tactics that may emerge under a Trump presidency moves from potential perceptions of threat to actual contact with individuals who may be impacted by such actions. The results in Table 1 provide strong evidence that 
knowing undocumented people also has a positive and significant effect on support for activism on immigration issues. This result can be explained by Latinos likely wanting people in their social network who are undocumented to be protected through the expansion of immigrant rights that could occur via activism and mass mobilization.

\section{Past Participation in Protests}

The results of the models indicate a strong and positive effect of past participation in a protest on Latino support for immigrant rights activism. As mentioned in our literature review, during the 2006 protest wave, Latinos were extremely supportive of the series of demonstrations and believed it was the start of a new and lasting social movement. Thus, it is not surprising that those who have recently participated in marches would also be more likely to support contemporary activism in favor of immigrant rights.

\section{Republicans}

The Republican Party advocates restrictive immigration policies, which are typically opposed by immigrant rights activists (Wallace 2014; Wong 2017; Nicholls 2013; ZepedaMillán 2017). Thus, it is reasonable to assume that most Republicans would not support legislation or policies that seek to expand immigrant rights. However, it is possible that Latino Republicans may have felt differently on immigration because of the personal nature of the issue for the Latino community. The role of partisanship amongst Latinos has consistently explained Latino political attitudes with Republicans demonstrating different policy positions and attitudes than their Democratic counterparts (Abrajano and Alvarez 2010; Casellas and Wallace 2015). Thus, as expected, our results indicate that Latino Republicans are less supportive of immigrant rights activism than non-Republican Latino respondents. ${ }^{14}$ While, these results are consistent

\footnotetext{
${ }^{14}$ One may wonder whether Latinos who voted for Trump were also less supportive of immigrant rights activism. Trump supporters are less supportive than Clinton voters. Latinos who voted for Clinton overwhelmingly support
} 
with our theoretical expectations, it is important to demonstrate that there is meaningful variation in support for immigrant rights activism amongst Latinos.

\section{Nativity and Ancestry}

Both nativity and ancestry play important roles in explaining Latino attitudes (Fraga et al. 2011). The literature generally finds that Latinos of Mexican and Puerto Rican decent tend to be the most liberal, while Cubans tend to be more conservative (García Bedolla 2003; Segura and Bowler 2005). With regards to nativity, whether Latinos were born in the U.S. can also play a role in explaining political attitudes (Fraga et al. 2010). Our results indicate that both nativity and ancestry are important factors in explaining support for immigrant rights activism. Latinos who are born in the U.S. are less likely to support immigrant rights activism compared to Latinos born outside of the country. This result may seem surprising given the impact of immigration on the Latino community as a whole and given the prevalence of mixed status families. However, a closer look at the raw levels of support among U.S. born Latinos compared to the total Latino sample reveals comparable support, 51\% v. 53\%. Foreign born Latinos are simply even more supportive of immigrant rights activism, with $67 \%$ of respondents expressing these sentiments.

As described above, in our models we use national origin group variables for the largest groups among the Latino population: Cubans, Mexicans, Puerto Ricans, and Dominicans. The results show that individuals of Mexican and Puerto Rican decent are more likely to support immigrant rights activism. However, the result for Mexican is only significant at the $10 \%$ level. These findings are consistent with typically more liberal views held by Latinos of Mexican and Puerto Rican descent. In addition, since activism has been an engrained form of political

immigrant rights activism. Whereas, Trump voters had nearly equal percentages of individuals who supported and opposed for immigrant rights activism. This pattern is also true of Latino Republicans. While not all Latinos who voted for Trump are Republicans, the correlation between Latino Republicans and Latino Trump voters in this sample is .63. 
participation within these communities (e.g., the Chicano, Young Lords, and Puerto Rican Independence movements), they may be more likely to support immigrant rights activism today because of their beliefs in such tactics' efficacy in bringing about political change. But there may also be more personal reasons for their support of immigrant rights activism as well. Our Mexican result may be partially explained by the large proportion of undocumented immigrants who are Mexican, thus support for immigrant rights activism may be more deeply relevant to them on a personal level (Zepeda-Millan 2014). With regards to Puerto Ricans, given that they are the only Latino national origin group who are automatically born with U.S. citizenship, they may find it particularly egregious that they are racialized as immigrants and thus support fighting for equal rights for Latino non-citizens with whom they see their fates as linked. These factors are what, at least partially, motivated some Puerto Ricans to participate in the 2006 demonstrations (Rodriguez Muniz 2010). The findings of our models thus indicate that racialization, identity, social networks, and partisanship play the most significant roles in explaining Latino public attitudes towards immigrant rights activism.

\section{Substantive effects}

Because the raw coefficients from ordered logit estimators are difficult to interpret on their own, we also estimate the substantive effects of each variable on support for immigrant rights activism. Figure 1 displays the first differences in the probability a respondent will indicate any level of support for immigrant rights activism when changing each variable from its minimum to maximum values, while holding all other variables constant at their means. ${ }^{15} 95 \%$ confidence intervals for each first difference are indicated by horizontal lines.

\section{INSERT FIGURE 1 HERE}

\footnotetext{
${ }^{15}$ All values are calculated using the -mchange- command from the SPost software package (Long and Freese 2014). For dichotomous variables, the first difference represents a change from 0 to 1 , whereas for continuous variables the estimate shows the first differences as a result from moving from the minimum to the maximum value.
} 
Substantively, the impact of racialization, identity, concerns over immigration enforcement, past participation in protests, partisanship and one's social network are critical in explaining support for immigrant rights activism. The main identity variable of interest is the linked fate item. When moving from Latinos who do not see their fates as linked to those Latinos who strongly believe in linked fate, the probability of supporting activism increases by nearly 10.5-percentage points. The measure we utilized for social networks was whether a respondent knows someone who is undocumented, had a roughly comparably sized effect to the link fate measure with a 12- percentage point effect. Taken together, these variables have modest positive effects on increasing support for activism.

Since we are directly assessing Latino support for immigrant rights activism, whether individuals have participated in protests could directly influence their levels of support of activism in this area. Recall our protest participation measure is modest in the sense that it only asks respondents whether they have participated in a protest in the last 12 months. The results from the statistical models indicate a strong and positive effect. Substantively, respondents who had participated in a protest were 16-percentage points more likely to support immigrant rights activism. Thus, provided strong evidence of a link between past protest participation and support for activism on immigrant rights.

Turning toward the variable that measures concerns about immigration enforcement, along with the variable that measures perceptions of whether anti-immigrant sentiments are really anti-Latino sentiments, the results indicate more considerable impacts of these two variables on support for immigrant rights activism. Concerns over potential immigration enforcement against someone a respondent knows results in a 23-percentage point increase in the likelihood of supporting immigrant rights activism. An even larger substantive effect is produced 
by whether respondents believe that anti-immigrant sentiments are really anti-Latino sentiments. For individuals who view these forms of discrimination as equivalent, there is an enormous change in the probability of support for immigrant rights activism, resulting in an almost 60percentage point increase. In other words, believing that immigration has been negatively racialized as synonymous with Latinos dramatically shifts support for immigrant rights activism.

On the other hand, two factors reduce the likelihood of Latino support for activism on immigration issues. The substantive effect of being a Latino Republican results in a 15-point decrease in the probability of supporting immigrant rights activism. This result is likely explained by the Republican Party's position on immigration, which tends to be in favor of more restrictive policies and against those expanding immigrant rights. Thus, partisanship continues to have a substantial impact on explaining variation in levels of support for immigrants, even amongst Latino Republicans. Somewhat more surprisingly, being born in the U.S. is associated with nearly a 12-point decrease in support for immigrant rights activism. It is important to note, however, that this does not mean that U.S. born Latinos are not in favor of contentious politics on behalf of immigrants, their raw levels of support were at about 51\%. Rather, in comparison to foreign born Latinos, they have a lower probability of support. Country of origin and general socio-demographics traits have fairly modest substantive impacts overall on attitudes towards immigrant rights activism. We now turn to a discussion of the implications of our findings and conclude by contextualizing our results under the current political climate.

\section{Conclusion}

The next four to eight years promise to be challenging ones for the U.S. immigrant rights movement. In his rhetoric, cabinet appointments, and executive actions, Donald Trump has made it crystal clear that immigrants and their rights will be under assault during his presidency. Under 
a Trump Administration, movement organizers are currently scrambling to figure out how best to defend themselves from what seems to be the most openly anti-immigrant and anti-Latino president in contemporary American history. Consequently, with unified Republican control of the federal government - the White House, the bureaucracy, and both chambers of Congress immigrant rights activists would be hard-pressed to believe that pursing traditional institutional routes of exerting political influence (e.g., lobbying, pushing for legislation, etc.) would prove to be fruitful efforts.

Although contentious politics may not have resulted in the passage of comprehensive immigration reform the last time Republicans fully controlled Washington (in 2006), mass mobilizations across the country by millions of Latinos and their allies did help fend off the notorious Sensenbrenner Bill (H.R. 4437), one of the most draconian anti-immigrant laws ever to pass the U.S. House of Representatives (Pallares and Flores-Gonzalez 2010; Voss and Bloemraad 2011; Zepeda-Millan 2017; Nicholls and Uitermark 2017). As such, because we believe contentious politics will once again be a vital tool for defending the rights of the foreignborn under the Trump Administration, in this article we explored the factors that impact Latino support for immigrant rights activism. Out findings make important contributions to several areas of research.

Theoretically, although the literature on the Latino racialization of immigration has helped us comprehend the links between Latino identity and the issue of immigration, it has said relatively little about how this phenomenon impacts Latinos' opinions about political activism. Similarly, research on linked fate and political behavior suggest that nativist public policies can augment the likelihood that Latinos will participate in contentious forms of politics, but says almost nothing about whether these same types of policies impact the general Latino public's 
opinions about activism. And, lastly, scholars have shown that the composition of Latino social network influenced their participation in the 2006 marches, and continues to play a role in Latino civic engagement (Terriquez and Lin 2017). However, whether these findings continue to motivate Latino support for immigrant rights activism over a decade after the unprecedented protest wave had yet to be explored.

Our study contributes to these literatures by showing that factors related to Latino identity, racialization, concerns over punitive enforcement policies, and social networks, all impact their support for contemporary immigrant rights activism. More specifically, our findings show that when Latinos believe that anti-immigrant sentiments are really anti-Latino sentiments, and when they feel that their individual fates are linked to those of the larger Latino community's, they are more likely to be in favor of contentious politics on behalf of the foreignborn. As such, contributing to the literature on the Latino racialization of immigration, our findings suggest that the close relationship between immigration and Latino identity can have important political implications.

Our results related to how punitive immigration policies and social networks also highlight the relevance of the immigration issue to Latinos. Since, as mentioned earlier, most Latinos are either relatives, friends, co-workers, neighbors of, or immigrants themselves, we posited that knowing someone who is undocumented or who may be detained or deported would yield positive results in our models. Our hypotheses were correct on these matters. Knowing people without papers or who are potentially negatively impacted by anti-immigrant legislation increases the likelihood that Latinos will support immigrant rights activism.

In conclusion, despite one of the main goals of movement organizers being to increase levels of support for their actions, the relationship between public opinion and social movements 
has been a relatively understudied area of academic inquiry. Given the Trump Administration's targeting of Latinos and immigrants, understanding the factors that drive support for actions such as political protests, marches, and demonstrations is of the utmost importance. As such, our study reveals valuable insights for both scholars and activists showing that when it comes to Latinos in the United States, issues related to the racialization of their identities, nativist immigration policies, and social networks play fundamental roles in explaining their levels of support for immigrant rights activism. 


\section{Tables and Figures}

Table \#1: Determinants of Support for Immigrant Rights Activism (Ordered Logit)

\begin{tabular}{|c|c|}
\hline & (1) \\
\hline \multirow[t]{2}{*}{ Linked Fate } & $0.149^{*}$ \\
\hline & $(0.0648)$ \\
\hline \multirow[t]{2}{*}{ Worried Imm Enforcement } & $0.252 * *$ \\
\hline & $(0.0579)$ \\
\hline \multirow[t]{2}{*}{ Anti-Imm=Anti-Latino } & $0.694 * *$ \\
\hline & $(0.0778)$ \\
\hline \multirow[t]{2}{*}{ Know Undocu. Person } & $0.511 * *$ \\
\hline & $(0.161)$ \\
\hline \multirow[t]{2}{*}{ Protest Participant } & $0.763^{* *}$ \\
\hline & $(0.287)$ \\
\hline \multirow{2}{*}{ Republican } & $-0.626 * *$ \\
\hline & $(0.147)$ \\
\hline \multirow[t]{2}{*}{ Income } & 0.00612 \\
\hline & $(0.0240)$ \\
\hline \multirow[t]{2}{*}{ Male } & 0.212 \\
\hline & $(0.131)$ \\
\hline \multirow[t]{2}{*}{ Age } & -0.0000951 \\
\hline & $(0.00519)$ \\
\hline \multirow[t]{2}{*}{ Education } & 0.103 \\
\hline & $(0.0648)$ \\
\hline \multirow[t]{2}{*}{ Mexican } & $0.289+$ \\
\hline & $(0.169)$ \\
\hline \multirow[t]{2}{*}{ Puerto Rican } & $0.424^{*}$ \\
\hline & $(0.194)$ \\
\hline \multirow{2}{*}{ Dominican } & 0.171 \\
\hline & $(0.357)$ \\
\hline \multirow[t]{2}{*}{ Cuban } & 0.0300 \\
\hline & $(0.326)$ \\
\hline \multirow[t]{2}{*}{ Born in U.S. } & $-0.529 * *$ \\
\hline & $(0.160)$ \\
\hline Observations & 2758 \\
\hline Pseudo R-squared & 0.176 \\
\hline Log Likelihood & -1975.8 \\
\hline Chi-squared & 234.7 \\
\hline
\end{tabular}

Standard errors in parentheses. Survey weights included.

$+\mathrm{p}<.10 ;{ }^{*} \mathrm{p}<.05 ; * * \mathrm{p}<.01$. Cutpoints not shown. 
Figure 1: Substantive Effects of Support for Immigrant Rights Activism

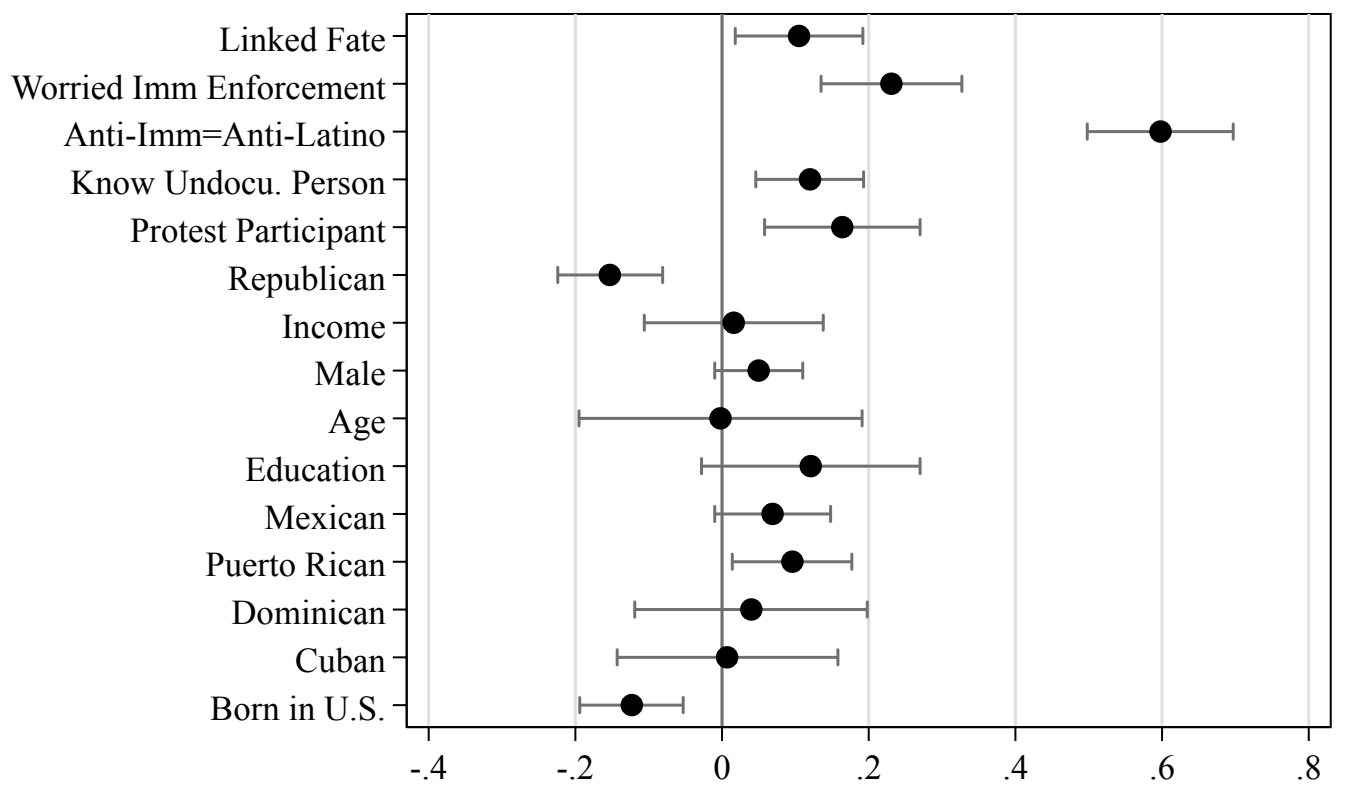

Results are generated from Model 1 in Table 1. Values represent first differences for each variable on the probability of the respondent indicating any level of support (strongly or somewhat) for immigrant rights activism, while setting all other variables at their means Continuous variables are changed from their minimum to maximum values, while binary variables change from 0 to 1 . 


\section{References}

Abrajano, Marisa A, and R Michael Alvarez. 2010. New Faces, New Voices: The Hispanic Electorate in America. Princeton, N.J.: Princeton University Press.

Andrews, Kenneth, Kraig Beyerlein, and Tuneka Tucker Farnum. 2016. "The Legitimacy of Protest: Explaining White Southerners' Attitudes Toward the Civil Rights Movement.” Social Forces. 94 (3) 3:1021-1044.

Barreto, Matt. A., Syliva Manzano, Ricardo Ramirez, and Kathy Rim. 2009. "Mobilization, Participation, and Solidaridad: Latino Participation in the 2006 Immigration Protest Rallies.” Urban Affairs Review. 44 (5):736-764.

Barreto, Matt, Lorrie Frasure-Yokley, Edward D. Vargas, and Janelle Wong. 2017. The Collaborative Multiracial Post-Election Survey (CMPS), 2016. Los Angeles, CA. Banaszak, Lee Ann and Heather Ondercin. 2016. "Public Opinion as a Movement Outcome: The Case of the U.S. Women's Movement." Mobilization: An International Quarterly. 21(3): $361-378$.

Benford, Robert. 1993. “Frame Disputes within the Nuclear Disarmament Movement.” Social Forces. 71(3): 677-701.

Benvington, Douglas and Chris Dixon. "Movement-Relevant Theory: Rethinking Social Movement Scholarship and Activism.” Social Movement Studies. 4 (3): 185-208.

Bloch, Katrina. 2014. ““Anyone can be Illegal': Color-Blind Ideology and Maintaining Latino/Citizen Borders.” Critical Sociology. 40(1):47-65.

Bloemraad, Irene and Christine Trost. "It's a Family Affair: Intergenerational Mobilization in the Spring 2006 Protests.” American Behavioral Scientist. Vol. 52, Iss. 4, 2008. 
Brown Hana and Laura Lopez-Sanders. 2017. "Immigration News Coverage and the Legacy of the 2006 Protests in new Immigrant Destinations."

Casellas, Jason P., and Sophia J. Wallace. 2015. “The Role of Race, Ethnicity, and Party on Attitudes Toward Descriptive Representation." American Politics Research. 43 (1):144169.

Chavez, Leo. 2008. The Latino Threat. Palo Alto, CA: Stanford University Press.

Costain, Anne and Steven Majstorovic.1994. "Congress, Social Movements and Public Opinion: Multiple Origins of Women's Rights Legislation.” Political Research Quarterly. 46 (1):111-135.

Dawson, Michael. 1994. Behind the Mule: Race and Class in African-American Politics. Princeton, NJ: Princeton University Press.

De Genova, Nicholas. 2004. “The Legal Production of Mexican/Migrant 'Illegality'.” Latino Studies. 2(2): 160-185.

DeSipio, Louis and Rodolfo de la Garza. 2015. US Immigration in the Twenty-First Century. Boulder, CO: Westview Press.

de la Garza, Rodolfo, Angelo Falcon, F. Chris Garcia, and John A. Garcia. 1989-1990. Latino National Political Survey. Inter-university Consortium for Political and Social Research.

Everitt, Joanna.1998. 'Public Opinion and Social Movements: The Women's Movement and the Gender Gap in Canada.” Canadian Journal of Political Science. 31 (4): 743-765.

Ferree, Myra Marx, William Gamson, Jurgen Gerhards, and Dieter Rucht. 2002. Shaping Abortion Discourse: Democracy and the Public Sphere in Germany and the United States. New York, NY: Cambridge University Press. 
Flacks, Richard. "Knowledge for what? Thoughts on the State of Social Movement Studies." Rethinking Social Movements: Structure, Culture, and Emotion. Eds. Jeff Goodwin and James Jasper. Lanham, MD: Rowman \& Littlefield.

Fraga, Luis, John A Garcia, Rodney E. Hero, Michael Jones- Correa, Valerie Martinez-Ebers, and Gary M. Segura. 2010. Latino Lives in America: Making it Home. Philadelphia, PA: Temple University Press.

Fraga, Luis R., John A. Garcia, Rodney Hero, Michael Jones-Correa, Valerie Martinez-Ebers, and Gary M. Segura. Latino National Survey (LNS), 2006. ICPSR20862-v6. Ann Arbor, MI: Inter-university Consortium for Political and Social Research [distributor], 2013-0605. http://doi.org/10.3886/ICPSR20862.v6

Fraga, Luis R., John A. Garcia, Rodney E. Hero, Michael Jones-Correa, Valerie Martinez-Ebers, and Gary M. Segura. 2011. Latinos in the new millennium: An almanac of opinion, behavior, and policy preferences. New York, NY: Cambridge University Press.

Gamson, William. 2007. "Bystanders, Public Opinion, and the Media.” The Blackwell Companion to Social Movements. Eds. David Snow, Sarah A. Soule, and Hanspeter Kriesi. Malden, MA: Blackwell.

García Bedolla, Lisa. 2005. Fluid Borders: Latino Power, Identity, and Politics in Los Angeles. Berkeley: University of California Press.

García Bedolla, Lisa. 2014. Latino Politics. Cambridge, UK: Polity Press.

Gonzales, Alfonso. 2013 Reform Without Justice: Latino Migrant Politics and the Homeland Security State. New York, NY: Oxford University Press.

Johnson, Kevin R. 2004. The "Huddled Masses” Myth: Immigration and Civil Rights. Philadelphia, PA: Temple University Press. 
Jones-Correa, Michael., Sophia. J. Wallace, and Chris Zepeda-Millán. 2016. "The Impact of Large-Scale Collective Action on Latino Perceptions of Commonality and Competition with African Americans." Social Science Quarterly. 97 (2):458-475.

Klandersman, Bert. 1984. "Mobilization and Participation: Social-Psychological Expansions of Resource Mobilization Theory.” American Sociological Review. 49 (5):583-600.

Klandermans, Bert. 2007. “The Demand and Supply of Participation: Social-Psychological Correlates of Participation in Social Movements." The Blackwell Companion to Social Movements. Eds. David Snow, Sarah A. Soule, and Hanspeter Kriesi. Malden, MA: Blackwell.

Lee, Taeku. 2002. Mobilizing Public Opinion: Black Insurgency and Racial Attitudes in the Civil Long, J. Scott and Jeremy Freese. 2014. Regression models for categorical dependent variables using Stata. College Station, TX: Stata press.

Martinez, Lisa. 2008. "The Individual and Contextual Determinants of Protest among Latinos." Mobilization. 13(2): 180-204.

Masuoka, Natalie. 2008. "Defining the group: Latino identity and political participation." American Politics Research. 36(1):33-61.

McCammon, Holly. 2001. "Stirring up Suffrage Sentiment: The Formation of the State Woman Suffrage Organizations, 1866-1944.” Social Forces. 80 (2):449-480.

McClain, Paula, Jessica Johnson Carew, Eugene Walton, and Candis Watts. 2009. “Group Membership, Group Identity, and Group Consciousness: Measures of Racial Identity in American Politics?” Annual Review of Political Science, Vol. 12: 471-485.

Ngai, Mae. 2005. Impossible Subjects: Illegal Aliens and the Making of Modern America. Princeton, NJ: Princeton University Press. 
Nicholls, Walter. 2013. The DREAMers: How the undocumented youth movement transformed the immigrant rights debate. Palo Alto, CA: Stanford University Press.

Nicholls, Walter and Justus Uitermark. 2017. "Going National: How the Struggle for Immigrant Rights became a National Social Movement."

Oegema, Dirk and Bert Klandermans. 1994. "Why Social Movement Sympathizers Don't Participate: Erosion and Nonconversion of Support.” 59(5): 703-722.

Okamoto, Dina and Kim Ebert. 2010. "Beyond the Ballot: Immigrant Collective Action in Gateways and New Destinations in the United States." Social Problems. (57) 4: 529-558. Pallares, Amalia and Nilda Flores-Gonzalez. 2010. Marcha!: Latino Chicago and the Immigrant Rights Movement. Champaign, IL: University of Illinois Press.

Passel, Jeffrey S., and D’vera Cohn. 2016. Overall Number of U.S. Unauthorized Immigrants Holds Steady Since 2009. Pew Research Center: Hispanic Trends.

Pedraza, Francisco, Gary Segura, and Shaun Bowler. 2011. "The Efficacy and Alienation of Juan Q. Public: The Immigration Marches and Orientation toward American Political Institutions." Rallying for Immigrant Rights: The Fight for Inclusion in $21^{\text {st }}$ Century America. Bloemraad, Irene and Kim Voss. Berkeley, CA: University of California Press. Ponce, Albert. 2014. "Racialization, Resistance and the Migrant Rights Movement: A Historical Analysis." Critical Sociology. 40(1): 9-27.

Ramírez, Ricardo. 2013. Mobilizing Opportunities: The Evolving Latino Electorate and the Future of American Politics. Charlotte, VA: University of Virginia Press.

Rocco, Raymond. 2014. Transforming Citizenship: Democracy, Membership, and Belonging in Latino Communities. Lansing, MI: Michigan State University Press.

Sanchez, Gabriel. R. 2006a. "The role of group consciousness in Latino public opinion." 
Political Research Quarterly. 59 (3):435-446.

Sanchez, Gabriel R. 2006b. "The role of group consciousness in political participation among Latinos in the United States." American Politics Research. 34 (4):427-450.

Sanchez, Gabriel R, and Natalie Masuoka. 2010. "Brown-utility heuristic? The presence and contributing factors of Latino linked fate." Hispanic Journal of Behavioral Sciences. 32 (4):519-531.

Sanchez, Gabriel R, Edward Vargas, Vickie Ybarra, and Hannah Walker. 2015. "Stuck between a Rock and a Hard Place: The Relationship Between Latino/A's Personal Connections to Immigrants and Issue Salience and Presidential Approval.” Politics, Groups, and Identities. 3(3):454-468.

Santa Ana, Otto. 2002. Brown tide rising: Metaphors of Latinos in contemporary American public discourse. Austin, TX: University of Texas Press.

Silber Mohamed, Heather. 2013. "Can protests make Latinos “American”? Identity, immigration politics, and the 2006 marches." American Politics Research. 41 (2):298-327.

Stokes, Atiya Kai. 2003. "Latino Group Consciousness and Political Participation." American Politics Research. 31(4): 361-378.

Street, Alex, Chris Zepeda-Millán, and Michael Jones-Correa. 2015. "Mass Deportation and the Future of Latino Partisanship.” Social Science Quarterly. 96(2): 540-552.

Suro, Roberto and Gabriel Escobar. 2006. "National Survey of Latinos." Pew Research Center. http://www.pewhispanic.org/2006/07/13/2006-national-survey-of-latinos/

Tarrow, Sydney. 1998. Power in Movement: Social Movements and Contentious Politics. $2^{\text {nd }}$ Edition. Cambridge, UK: Cambridge University Press.

Terriquez, Veronica and May Lin. 2017. "Yesterday they marched, today they mobilized the 
vote: A developmental model for civic leadership among the children of immigrants." Valdez, Zulema. 2011. "Political Participation among Latinos in the United States: The Effect of Group Identity and Consciousness." Social Science Quarterly. 92 (2): 466-82.

Vargas, Edward, Gabriel Sanchez, and Juan Valdez. Forthcoming. "Immigration Policies and Group Identity: How Immigrant Laws Affect Linked Fate among U.S. Latino Populations." Journal of Race, Ethnicity and Politics. doi:

\section{https://doi.org/10.1017/rep.2016.24}

Verba, Sidney, Key Lehman Schlozman, and Henry E. Brady. 1995. Voice and Equality: Civic Voluntarism in American Politics. Cambridge, MA: Harvard University Press.

Voss, Kim and Irene Bloemraad. 2011. Eds. Rallying for Immigrant Rights: The Fight for Inclusion in $21^{\text {st }}$ Century America. Berkeley, CA: University of California Press. Vrablikova, Katerina. 2013. "Public Opinion and Movements.” The Wiley-Blacwell Encyclopedia of Social \& Political Movements. Vol. III, Malden, MA: Wiley-Blackwell.

Wallace, Sophia J., Chris Zepeda-Millán, and Michael Jones-Correa. 2014. "Spatial and Temporal Proximity: Examining the Effects of Protests on Political Attitudes." American Journal of Political Science. 58 (2):433-448. doi: 10.1111/ajps. 12060.

Wallace, Sophia J. 2012. "It's Complicated: Latinos, President Obama, and the 2012 Election." Social Science Quarterly. 93 (5):1360-1383.

Wallace, Sophia. J. 2014. "Representing Latinos: Examining Descriptive and Substantive Representation in Congress." Political Research Quarterly. 67 (4):917-929.

Wallace, Sophia J. 2014. "Papers Please: State-Level Anti-Immigrant Legislation in the Wake of Arizona's SB 1070." Political Science Quarterly. 129 (2):261-291.

Wang, Amy B. 2016. "Donald Trump plans to immediately deport 2 to 3 million undocumented 
immigrants. Washington Post. Nov. 14. https://www.washingtonpost.com/news/thefix/wp/2016/11/13/donald-trump-plans-to-immediately-deport-2-to-3-millionundocumented-immigrants

Wong, Tom K. 2017. The Politics of Immigration: Partisanship, Changing Demographics, and the American National Identity. New York, NY: Oxford University Press.

Wroe, Andrew. 2008. The Republican party and immigration politics: from Proposition 187 to George W. Bush. New York, NY: Palgrave Macmillan.

Zepeda-Millán, Chris. 2014. "Perceptions of Threat, Demographic Diversity, and the Framing of Illegality: Explaining (Non) Participation in New York's 2006 Immigrant Protests." Political Research Quarterly, 67(4): 880-88.

Zepeda-Millán, Chris. 2016. "Weapons of the (not so) weak: Immigrant mass mobilization in the US South." Critical Sociology. 42 (2):269-287.

Zepeda-Millán, Chris. 2017. Latino Mass Mobilization: Immigration, Racialization, and Activism New York, NY: Cambridge University Press.

Zepeda-Millán, Chris and Sophia Wallace. 2013 "Racialization in Times of Contention: How Social Movements Influence Latino Racial Identity.” Politics, Groups, Identities. 1(3): $510-27$. 
Appendix-Substantive Survey Items from CMPS used in Models (2016)

[L300] How strongly do you support or oppose Immigrant Rights activism?

Strongly support

Somewhat support

Neither support or oppose

Somewhat oppose

Strongly oppose

Modified 3-point item

Oppose (Combines Strongly and Somewhat) 0

Neither support or oppose

Support (Combines Strongly \& Somewhat) 2

[L366] How worried are you that people you know might be detained or deported for immigration reasons?

Extremely worried

Very worried

Somewhat worried

A little worried

Not at all worried
4

3

2

1

0

[L301] Do you agree or disagree with the following statement: Anti-immigrant sentiments are really anti-Latino sentiments.

Strongly Disagree

Somewhat Agree

Neither Disagree or Agree

2

Neither Disagree or Agree

Somewhat Agree

Strongly Agree

[L364] Now take a moment to think about all the people in your family, your friends, coworkers, and other people you know. Do you happen to know somebody who is an undocumented immigrant? This is completely anonymous and is just for simple demographic analysis.

Yes

No/Don't Know 
[C150 \& 151] Combined two items to create one scale of Latino linked fate.

Do you think what happens generally to Latino/Hispanic people in this country will have something to do with what happens in your life?

For those answered yes, will it affect you?

$\begin{array}{ll}\text { A lot } & 3 \\ \text { Some } & 2 \\ \text { Not very much } & 1 \\ \text { No/None } & 0\end{array}$

S10. [If Latino] Hispanics and Latinos have their roots in many different countries in Latin America. To what country do you or your family trace your ancestry?

Created binary variables for Mexico, Puerto Rico, Cuban, Dominican Republic $(0,1)$ 
Table A1: Descriptive Statistics of Variables

\begin{tabular}{lccccc} 
Variable & Observations & Mean & Std. Dev. & Min & Max \\
\hline Immigrant Rights Activism & 3,003 & 1.42 & 0.69 & 0 & 2 \\
Linked Fate & 3,003 & 1.28 & 1.19 & 0 & 3 \\
Worried Imm Enforcement & 3,003 & 1.44 & 1.46 & 0 & 4 \\
Anti-Imm=Anti-Latino & 3,003 & 3.29 & 1.12 & 1 & 5 \\
Know Undocu. Person & 3,003 & 0.38 & 0.48 & 0 & 1 \\
Participated in Protest & 3,003 & 0.12 & 0.32 & 0 & 1 \\
Republican & 3,003 & 0.21 & 0.41 & 0 & 1 \\
Income & 2,762 & 4.57 & 3.29 & 1 & 12 \\
Male & 3,003 & 0.32 & 0.47 & 0 & 1 \\
Age & 2,998 & 37.39 & 14.02 & 18 & 98 \\
Education & 3,003 & 3.98 & 1.15 & 1 & 6 \\
Mexican & 3,003 & 0.50 & 0.50 & 0 & 1 \\
Puerto Rican & 3,003 & 0.16 & 0.37 & 0 & 1 \\
Dominican & 3,003 & 0.04 & 0.19 & 0 & 1 \\
Cuban & 3,003 & 0.05 & 0.22 & 0 & 1 \\
Born in U.S. & 3,003 & 0.76 & 0.43 & 0 & 1 \\
\hline
\end{tabular}


Table A2: Determinants of Support for Immigrant Rights Activism (Ordered Logit with 5-point version of Outcome Variable)

\begin{tabular}{|c|c|}
\hline & $(1)$ \\
\hline \multirow[t]{2}{*}{ Linked Fate } & $0.186^{* *}$ \\
\hline & $(0.0558)$ \\
\hline \multirow[t]{2}{*}{ Worried Imm Enforcement } & $0.310 * *$ \\
\hline & $(0.0515)$ \\
\hline \multirow[t]{2}{*}{ Anti-Imm=Anti-Latino } & $0.723 * *$ \\
\hline & $(0.0778)$ \\
\hline \multirow[t]{2}{*}{ Know Undocu. Person } & $0.252+$ \\
\hline & $(0.145)$ \\
\hline \multirow[t]{2}{*}{ Protest Participant } & $0.778 * *$ \\
\hline & $(0.237)$ \\
\hline \multirow[t]{2}{*}{ Republican } & $-0.498 * *$ \\
\hline & $(0.152)$ \\
\hline \multirow[t]{2}{*}{ Income } & 0.0122 \\
\hline & $(0.0231)$ \\
\hline \multirow[t]{2}{*}{ Male } & 0.112 \\
\hline & $(0.119)$ \\
\hline \multirow[t]{2}{*}{ Age } & -0.00412 \\
\hline & $(0.00445)$ \\
\hline \multirow[t]{2}{*}{ Education } & 0.0663 \\
\hline & $(0.0589)$ \\
\hline \multirow[t]{2}{*}{ Mexican } & $0.271+$ \\
\hline & $(0.148)$ \\
\hline \multirow[t]{2}{*}{ Puerto Rican } & $0.444^{*}$ \\
\hline & $(0.177)$ \\
\hline \multirow[t]{2}{*}{ Dominican } & 0.128 \\
\hline & $(0.258)$ \\
\hline \multirow[t]{2}{*}{ Cuban } & -0.0198 \\
\hline & $(0.278)$ \\
\hline \multirow[t]{2}{*}{ Born in U.S. } & $-0.419 * *$ \\
\hline & $(0.138)$ \\
\hline Observations & 2758 \\
\hline Pseudo R-squared & 0.147 \\
\hline Log Likelihood & -3098.9 \\
\hline Chi-squared & 294.2 \\
\hline
\end{tabular}

Standard errors in parentheses. Survey weights included.

$+\mathrm{p}<.10 ; * \mathrm{p}<.05 ; * * \mathrm{p}<.01$. Cutpoints not shown. 